\title{
Social Networks and Credit Access in Indonesia
}

\author{
CAGLA OKTEN \\ Bilkent University, Ankara, Turkey \\ and \\ UNA OKONKWO OSILI * \\ Indiana University-Purdue University at Indianapolis, USA
}

\begin{abstract}
Summary. - In this paper, we investigate how family and community networks affect an individual's access to credit institutions using new data from the Indonesia Family Life Surveys. Our theoretical framework emphasizes the family and community's role in providing information, thus lowering the search costs of the borrower and monitoring and enforcement costs for the lender. From our empirical results, community and family networks are important in knowing a place to borrow, as well as for loan approval. Consistent with an information-based explanation of networks, family and community networks have a larger impact on credit awareness of new credit institutions with a lower impact on awareness of established credit sources. Interestingly, we find that women benefit from participating in community networks more than men. There is no evidence that the rich benefit from community networks more than the poor. Our results on the benefits from participation in the community network are robust to the inclusion of community fixed effects.
\end{abstract}

(c) 2004 Elsevier Ltd. All rights reserved.

Key words - credit access, social networks, Indonesia

\section{INTRODUCTION}

A fundamental issue facing individuals in less-developed countries (LDCs) is lack of access to credit. Credit markets allow individuals to smooth consumption in the face of highly variable incomes, provide capital for investment projects, and improve the ability to cope with unexpected expenditure shocks, including those associated with illness, crop loss, and unemployment. Recent evidence also suggests that improving access to credit markets may have an impact on the adoption of new technologies, nutrition, health, and education outcomes (Jacoby \& Skoufias, 1997; Morduch, 1999; Pitt \& Khandker, 1998).

This paper aims to contribute to important policy debates on the determinants of access to credit markets in developing countries. Some facts about credit markets are well-documented. In particular, lack of collateral, illiteracy, and high default risk can hinder an individual's access to credit in low-income environments (Adams \& Fitchett, 1992; Besley, 1995). Much less is understood about the specific role of social networks in enhancing credit access. A growing literature on microfinance suggests that nonmarket institutions can play an important role dealing with credit market

\footnotetext{
* The authors would like to thank RAND and Lembaga Demografi of the University of Indonesia for making the data available. We would also like to thank Kathleen Beegle, Victoria Beard, and Chris Peterson at RAND for their assistance. We have also benefited greatly from discussions with Kevin Hasker, Ifeanyi Osili, Richard Steinberg, Mark Wilhelm, and seminar participants at the 2001 NEUDC conference. Dan Du and Xiaojun Feng provided valuable research assistance. Financial support from the Indiana University Center on Philanthropy and the IFLS Small Grants Competition is gratefully acknowledged. Final revision accepted: 28 January 2004.
} 
imperfections. ${ }^{1}$ There is very little empirical work, however, that documents the role of community institutions in credit markets. ${ }^{2}$

In this paper, we investigate how family and community networks affect an individual's access to credit institutions using data from Indonesia. The emphasis here is on the family's and community's role in providing information about credit market opportunities, thus lowering the search costs of the borrower. Potential borrowers may learn about lending institutions and credit contracts through community activities and neighborhood meetings, or through informal interactions with neighbors and family members. In addition, family and community institutions may reduce monitoring costs and enforcement costs associated with credit contracts on the part of the lender.

Our focus on the relationship between networks and credit access informs a growing body of research on the impact of social institutions on economic outcomes (Fukuyama, 1995; Putnam et al., 1993). In this literature, features of social organization such as trust, norms, and networks that facilitate coordinated actions are called "social capital." According to Portes (1998, p. 6), social capital represents "the ability of actors to secure benefits by virtue of their membership in social networks and other social structures." Individuals may rely on various types of social networks, including family and community organizations, to cope with shocks and improve their access to services. In recent empirical work, social cohesion and other measures of community activity have been shown to have a positive impact on technology adoption and environmental outcomes (Grootaert, 1999; Isham, 2002; Narayan \& Pritchett, 1999). We investigate the extent to which community activity confers benefits by fostering information exchange about new credit opportunities and building trust among potential lending partners.

Identifying the relevant measures of the community network can be challenging. In our study, we rely on whether the individual has participated in the community meeting in the survey period. This variable reflects an individual's access to reliable information about credit market opportunities and also the degree to which community-level monitoring and sanctions can be effective for a given individual. We also measure the number of economically active siblings and family wealth in order to capture the extent and quality of the family network.
There are some notable concerns with our measure of the community networks. Individual-level participation in community activity may be an endogenous choice variable, if individuals who wish to borrow from credit sources also choose to participate actively in associational life. ${ }^{3}$ Our measure of family networks is less problematic since the number of economically active siblings is more likely to be exogenous to both the borrowing and lending decision. We attempt to address these issues using two methods: first, we address this problem using the instrumental variable approach. Candidate instruments are variables that are correlated with participation in community networks, but not directly correlated with the propensity to borrow in the survey period. We also control for the role of unobserved heterogeneity (such as infrastructure quality and community leadership) at the community level by adopting a community fixed-effects specification.

Our empirical results are based on a new longitudinal survey, the Indonesia Family Life Survey (IFLS) (Frankenberg \& Karoly, 1995; Frankenberg \& Thomas, 2000). The IFLS provides a representative sample of about $83 \%$ of the Indonesian population. ${ }^{4}$ In addition, the IFLS data provide unusually detailed measures of family and community networks, as well as information on access to credit. The data used in the survey also allow us to investigate how gender, household resources, and community characteristics affect the benefits from social networks within credit markets.

Our main results indicate that community and family networks are important in knowing a place to borrow and obtaining credit. Networks are particularly important in gaining knowledge about new credit sources, with less of an impact on established sources of credit. This suggests an information-based explanation of the role of networks in credit market transactions. Interestingly, we find that women benefit from participating in community networks more than men. Finally, social networks may play an important role in improving credit access among poor borrowers.

The rest of the paper is organized as follows: Section 2 provides a description of the setting. In Section 3, we present the conceptual framework. Section 4 discusses estimation methods. Section 5 discusses the data sources. In Section 6, we present results, and Section (7) concludes. 


\section{THE SETTING: CREDIT MARKETS, THE FAMILY, COMMUNITY INSTITUTIONS IN INDONESIA}

Indonesia's socioeconomic and geographic diversity provides a rich setting in which to explore the role of family and community networks in credit markets. Although community institutions may differ in their leadership, effectiveness, and socio-cultural environments across Indonesia, a recent history of centralization means that there are some similarities in local institutions across regions. ${ }^{5}$ In both rural and urban areas, town and village councils administer government programs and services in key sectors including health care and education. Community-level programs are often headed by a village chief (Kepala Desa) or by the head of an urban village unit (Kepala Kelurahan).

An important class of benefits provided by community organizations is information about existing services and programs. There is concern, however, that information about how to access new services may not always reach target populations, particularly when recent migrants, low-income groups, and women face low rates of participation in village and townlevel meetings. ${ }^{6}$ There is a need to raise awareness about new programs and services among the poor. ${ }^{7}$ In addition, a recent history of highly centralized and personal rule in Indonesia may have fostered an environment where households with family members and friends in government may enjoy greater access to community-level services.

Indonesia has witnessed a tremendous expansion in financial services over the past three decades as a result of economic growth and deregulation. Financial intermediation has evolved to include private banks, government banks, informal credit institutions such as money lenders and rotating savings and credit associations (ROSCAs), or arisans, as well as new credit sources, mainly co-operatives, 7neighborhood institutions, and new government programs aimed at improving access to credit among poor households (Seibel \& Parhusip, 2003).

One of the most well-established banks is the Bank Rakyat Indonesia (BRI), or People's Bank of Indonesia (Robinson, 1994). ${ }^{8}$ The modern BRI was established in 1950 and has grown to include an extensive network of over 4,000 banks that provide local financial services to approximately one-third of Indonesian households, mostly in rural areas. The BRI has a successful record in rural banking services and promoting the development of the agricultural sector. Interest rates on loans administered through the BRI are relatively low, but collateral is often required (usually in the form of a land certificate) to secure a loan. ${ }^{9}$ In general, the success of BRI lending programs may be linked to particular methods of gathering information, monitoring loans, and enforcing contracts. BRI agents (at the village level) visit potential and current borrowers, analyze cash flow and outstanding debts, and require character references from neighbors and community leaders. Community-level sanctions and loss of future access to credit, as well as the clients' sense of obligation to repay debts, are often cited as explanations for high rates of loan repayment (Churchill, 1999).

New government initiatives in the financial sector have aimed to promote savings and credit access by targeting poor households more directly. In August 1993, the Indonesian government launched a large-scale poverty reduction program called Inpres Desa Tertinggal (IDT), or Presidential Instruction on Backward Village, which channeled revolving funds (up to US $\$ 200$ million each year) to over 20,000 villages. The program provided assistance to poor villages, which were identified using economic and social indicators. The IDT program was run during 1994-97. Approximately $34 \%$ of rural villages were covered by the IDT program. The IDT funds (underdeveloped village grant) were provided to selfhelp groups consisting of poor families and were meant to be repaid over a specified period. Under the IDT program, credit allocation decisions fell under the authority of the village head and local residents.

The "family welfare savings" (TAKESRA) and "family welfare business credit" (KUKESRA) schemes were introduced in 1995. Both schemes grant priority to poor women in rural areas. Families who joined the saving fund were provided with an initial savings deposit of 2,000 Rupiah. To participate in the borrowing scheme, families are required to open a savings account and become a member of an income-generating project. One of the main objectives of the savings scheme was to provide initial capital for small business formation. The savings and borrowing program was managed by Indonesia's Nation Family Planning Coordinating Board (BKKBN). 
In both rural and urban areas in Indonesia, the informal sector continues to play a dominant role in credit provision despite the tremendous expansion in formal banking and financial services (Mukherjee, 2002). While formal credit institutions often rely on collateral to screen borrowers, informal credit market transactions tend to rely on reputation, third party guarantees, tied contracts, and threat of loss of future access to credit. Individuals may obtain informal credit through family, friends, employers, neighbors, money lenders, and rotating savings and credit associations (ROSCAs), or arisans. For poor urban and rural households, short-term credit is available through pawnshops and storeowners. In addition, small and medium-sized businesses often rely on informal trade credit from suppliers to finance production.

\section{CONCEPTUAL FRAMEWORK}

In this section, we discuss more formally how family and community networks can affect credit market transactions. Consider a given borrower who seeks credit for an investment project or to smooth consumption in the face of adverse shocks to income. For the potential borrower, the decision to apply to a specific credit source for a loan will depend on the availability of reliable information about lending institutions. Family and community networks can facilitate the flow of high-quality information about new credit market opportunities, thus lowering the search costs of the borrower.

There is an important theoretical literature that demonstrates how networks can facilitate the circulation of information about market opportunities. Kranton (1996) provides a model in which a decentralized network of pairwise interactions helps agents reduce search costs. Social interactions have been shown to play a role in technology adoption decisions within agriculture. In particular, farmers may share information and learn from each other about how to grow new crops or implement new farming techniques (see Conley \& Udry, 2003; Feder, Just, \& Zilberman, 1985; Foster \& Rosenzweig, 1995). Within the labor market context, networks can be effective in reducing search costs for job-seekers (Granovetter, 1974; Montgomery, 1991; Munshi, 2003). Drawing on this analogy, we investigate the role that community and family networks can play in raising awareness of new credit sources among potential borrowers.

Our framework predicts that individuals with stronger family and community networks will have greater access to credit because of their informational advantage, holding other variables constant. It is also possible that participation in community networks may have little or no impact on credit access if community activity does not prove useful in learning about new credit opportunities or gaining the trust of a new lending partner. While both family and community networks can facilitate the flow of information regarding credit opportunities, the family network may be limited in its ability to provide new information due to its limited group size and high correlation of incomes within the family network. In our setting, family networks can be classified as strong ties and may be less useful than weak ties (friends, acquaintances, and neighbors) in locating credit market opportunities (Granovetter, 1974). Thus, we predict that community networks will be relatively more important than family networks in gaining awareness of credit sources.

We recognize that the role of family and community networks may not be limited to the diffusion of knowledge about credit opportunities to potential borrowers. Within a formal model of credit rationing, borrowers differ in their default risk. Due to asymmetric information, lenders may limit the amount borrowed at the prevailing interest rate and allocate credit based on nonprice considerations (Stiglitz \& Weiss, 1981). There are often significant costs involved in screening borrowers, as well as in monitoring and enforcing credit contracts for both formal and informal lenders (Aleem, 1990). When agents interact frequently, patterns of expected behavior and bonds of trust are established, which can reduce the transaction costs of lending. Furthermore, the possibility of social sanctions may lower the probability of opportunistic behavior among borrowers.

When social networks circulate information about borrower characteristics and actions to lenders, the overall impact on credit outcomes may consist of two effects. First, networks may have a direct effect of credit market outcomes if they provide information on less observable borrower characteristics (such as ability, motivation, and trustworthiness), thus improving credit access for high-quality borrowers while reducing credit access for low-quality borrow- 
ers. Based on the direct effect alone, participation in a social network will have an ambiguous effect on obtaining credit. Second, networks may have an indirect effect on credit market outcomes if lenders simply exclude borrowers for whom they cannot collect accurate information. This will result in the screening out of whole sectors since credit institutions cannot easily distinguish between high-quality and low-quality potential borrowers outside the network (Stiglitz \& Weiss, 1981). ${ }^{10}$

We should note that networks may also have negative consequences if their presence distorts the allocation of credit within the community. While community institutions provide information and other benefits to those within the community network, certain groups (based on gender, ethnicity, or income) who are less likely to participate in community meetings may be excluded. ${ }^{11}$ Thus, the presence of strong community networks may reduce access to credit for some groups. Participating in networks often involves high monetary and time costs, which may prove to be a significant burden for the poor. Thus, strong family (or community) ties can pose barriers to credit access if individuals divert a portion of their loans away from productive activities and towards family and community needs. In such a case, one would expect that lenders would be less willing to provide credit to individuals with strong family and community ties (Fafchamps \& Minten, 2002).

\section{DATA}

The empirical analysis in this paper is based on the second wave of the Indonesia Family Life Surveys (IFLS2), conducted in 1997-98 by RAND. The second wave of the survey is composed of about 7,500 households ( $94 \%$ of the original sample was interviewed for the second wave and the sample also includes 800 split-offs). ${ }^{12}$ We focus on the second wave of the survey because detailed information on sources of credit and community networks are not available in the first wave of the survey, conducted in 1993-994 (IFLS1). We can, however, exploit the longitudinal aspect of the survey by using a rich set of family background and community variables available in IFLS1.

Our main dependent variable of interest is whether an individual has successfully obtained credit in the past 12 months. All adult respondents in the sample are also asked to indicate (from a list of new and established sources of credit) those institutions from which they successfully obtained credit in the past 12 months. Individuals can be classified according to whether they applied for credit, and whether their loan application was granted or denied. Forty-two percent of individuals surveyed have applied for credit. Among the credit applicants, $71 \%$ successfully obtained credit. The focus on the outcome of the credit application process allows us to investigate the relative importance of family and community networks in a specific context, where information is particularly relevant.

We should note that only individuals who indicate that they know a place to borrow are then asked whether they borrowed in the last 12 months, which introduces sample selection bias. From our data, $71 \%$ of individuals indicate that they know at least one place where they can borrow. We group credit sources included in the survey into two distinct categories: new credit sources and established credit institutions. We recognize that the distinction between new and established credit institutions may not always be well defined. To distinguish between new and established sources of credit in the community, we use the CommunityFacility Survey from IFLS1, which lists the main financial institutions in each community in 1993-94 and how long these have been in existence. We also rely on descriptive sources which provide information about new credit institutions in Indonesia (Seibel \& Parhusip, 2003).

In our analysis, sources of established credit refer to banks, moneylenders, workplace, pawnshops, employers, and arisans (rotating savings and credit institution). ${ }^{13}$ New credit institutions include cooperatives, savings/borrowing programs, village credit institutions, neighborhood associations, and IDT programs (underdeveloped village grants). While $60 \%$ of the sample reports awareness of established sources, only $33 \%$ report familiarity with new credit sources.

In Table 1, we present summary statistics for the full sample, individuals that applied for credit, and those that successfully obtained credit in the survey period. It is interesting to note the differences in network variables for loan applicants who were granted credit (compared to those who were denied credit). An average grantee is more likely to participate in community meetings and has more economically active siblings than an average applicant. 
Table 1. Summary statistics

\begin{tabular}{|c|c|c|c|c|c|c|}
\hline \multirow[t]{2}{*}{ Variables } & \multicolumn{2}{|c|}{ Full sample } & \multicolumn{2}{|c|}{ Applicants } & \multicolumn{2}{|c|}{ Grantees } \\
\hline & $N$ & Mean & $N$ & Mean & $N$ & Mean \\
\hline \multicolumn{7}{|l|}{ Credit indicators } \\
\hline Aware of a credit source ( $=1$ if aware) & 19,860 & 0.71 & 5,869 & 1.00 & 4,188 & 1.00 \\
\hline Aware of a new source ( $=1$ if aware) & 19,860 & 0.33 & 5,869 & 0.46 & 4,188 & 0.47 \\
\hline $\begin{array}{l}\text { Aware of an established source } \\
\quad(=1 \text { if aware })\end{array}$ & 19,860 & 0.59 & 5,869 & 0.77 & 4,188 & 0.74 \\
\hline $\begin{array}{l}\text { Apply ( }=1 \text { if applied for credit given that } \\
\text { aware of a credit source) }\end{array}$ & 14,106 & 0.42 & 5,869 & 1.00 & 4,188 & 1.00 \\
\hline $\begin{array}{l}\text { Granted ( }=1 \text { if granted credit given that } \\
\text { applied) }\end{array}$ & 5,869 & 0.71 & 5,869 & 0.71 & 4,188 & 1.00 \\
\hline \multicolumn{7}{|l|}{ Network characteristics } \\
\hline Number of economically active siblings & 17,052 & $\begin{array}{c}3.94 \\
(3.42)^{\mathrm{a}}\end{array}$ & 5,241 & $\begin{array}{c}4.63 \\
(3.46)\end{array}$ & 3,835 & $\begin{array}{c}4.84 \\
(3.37)\end{array}$ \\
\hline $\begin{array}{l}\text { Individual participation in community } \\
\text { meeting }\end{array}$ & 19,852 & 0.24 & 5,869 & 0.34 & 4,188 & 0.37 \\
\hline \multicolumn{7}{|l|}{ Individual characteristics } \\
\hline Head (= 1 if household head) & 19,860 & 0.33 & 5,869 & 0.42 & 4,188 & 0.43 \\
\hline $\operatorname{Sex}(=1 \mathrm{male})$ & 19,859 & 0.46 & 5,869 & 0.52 & 4,188 & 0.51 \\
\hline Marital status ( $=1$ married) & 19,851 & 0.65 & 5,812 & 0.76 & 4,188 & 0.81 \\
\hline Years schooling & 19,645 & $\begin{array}{c}6.52 \\
(4.39)\end{array}$ & 5,868 & $\begin{array}{c}7.08 \\
(4.44)\end{array}$ & 4,146 & $\begin{array}{c}6.87 \\
(4.49)\end{array}$ \\
\hline Muslim & 19,850 & 0.88 & 5,869 & 0.86 & 4,188 & 0.87 \\
\hline Age & 19,851 & $\begin{array}{l}37.30 \\
(16.57)\end{array}$ & 5,869 & $\begin{array}{l}38.00 \\
(14.01)\end{array}$ & 4,187 & $\begin{array}{c}38.68 \\
(13.24)\end{array}$ \\
\hline Age squared $\left(\times 10^{-3}\right)$ & 19,851 & $\begin{array}{l}1.67 \\
(1.44)\end{array}$ & 5,869 & $\begin{array}{l}1.57 \\
(1.37)\end{array}$ & 4,187 & $\begin{array}{l}1.67 \\
(1.13)\end{array}$ \\
\hline Government employee $(=1)$ & 11,323 & 0.07 & 4,993 & 0.12 & 2,980 & 0.12 \\
\hline Recent migrant $(=1)$ & 19,860 & 0.09 & 5,869 & 0.09 & 4,188 & 0.08 \\
\hline Average sibling & 12,355 & 0.12 & 3,918 & 0.14 & 2,922 & 0.15 \\
\hline Nonfarm business & & $(0.24)$ & & $(0.25)$ & & $(0.26)$ \\
\hline Frequency of visits with siblings & 13,394 & $\begin{array}{l}3.26 \\
(0.96)\end{array}$ & 4,522 & $\begin{array}{l}3.26 \\
(0.92)\end{array}$ & 3,383 & $\begin{array}{c}3.28 \\
(0.91)\end{array}$ \\
\hline \multicolumn{7}{|l|}{ Household variables } \\
\hline Per capita household expenditure $\left(\times 10^{-6}\right)$ & 17,906 & $\begin{array}{c}0.20 \\
(0.29)\end{array}$ & 5,221 & $\begin{array}{c}0.22 \\
(0.28)\end{array}$ & 3735 & $\begin{array}{c}0.23 \\
(0.29)\end{array}$ \\
\hline Business owner in household & 19,849 & 0.36 & 5,865 & 0.39 & 4,186 & 0.40 \\
\hline Farm owner in household & 19,849 & 0.32 & 5,865 & 0.30 & 4,186 & 0.51 \\
\hline Household debt in $1993\left(\times 10^{-2}\right)$ & 18,100 & $\begin{array}{c}4806.70 \\
(42081.8)\end{array}$ & 5,383 & $\begin{array}{c}5876.09 \\
(46939.0)\end{array}$ & 3,275 & $\begin{array}{c}5078.1 \\
(39,159)\end{array}$ \\
\hline Household size & 19,859 & $\begin{array}{l}5.93 \\
(2.64)\end{array}$ & 5,869 & $\begin{array}{l}5.91 \\
(2.66)\end{array}$ & 4,188 & $\begin{array}{l}5.65 \\
(2.50)\end{array}$ \\
\hline \multicolumn{7}{|l|}{ Community characteristics } \\
\hline $\begin{array}{l}\text { Distance to nearest financial } \\
\text { Institution (in } \mathrm{km} \text { ) }\end{array}$ & 18,123 & $\begin{array}{c}3.72 \\
(7.51)\end{array}$ & 5,372 & $\begin{array}{c}3.23 \\
(6.81)\end{array}$ & 3,841 & $\begin{array}{c}3.18 \\
(6.64)\end{array}$ \\
\hline Urban & 19,859 & 0.48 & 5,869 & 0.50 & 4,188 & 0.48 \\
\hline Ethnic diversity index & 19,860 & $\begin{array}{c}0.29 \\
(0.37)\end{array}$ & 5,869 & $\begin{array}{c}0.28 \\
(0.36)\end{array}$ & 4,188 & $\begin{array}{c}0.27 \\
(0.36)\end{array}$ \\
\hline Gini coefficient & 18,206 & $\begin{array}{c}0.54 \\
(0.04)\end{array}$ & 5,385 & $\begin{array}{c}0.54 \\
(0.04)\end{array}$ & 3,854 & $\begin{array}{c}0.54 \\
(0.04)\end{array}$ \\
\hline
\end{tabular}

${ }^{\text {a }}$ Standard deviations are shown in parentheses. 
This observation provides some preliminary evidence that family and community networks may impact an individual's participation in credit markets.

We also observe differences in individual and community characteristics when we compare individuals who obtained loans with an average applicant. For example, a successful loan applicant is more likely to come from a farmowning household and live in closer proximity to a financial institution than an applicant who was denied credit. This observation points out the importance of controlling for such individual and community characteristics in our analysis.

\section{(a) Individual and household variables}

In our empirical analysis, we control for the following individual characteristics: age, age squared, schooling, gender, marital status, household headship, and religion (Muslim =1). Recent migration experience and being a government employee can also affect an individual's awareness of and access to credit sources, and thus we control for these variables in some specifications.

It is important to recognize that the demand for credit may differ among households based on the nature of household production. We include indicators for the presence of a nonfarm enterprise owner or farm enterprise within the household. Variables that capture economic resources available to the individual include per capita household expenditure, household size, and debt burden.

\section{(b) Family network variables}

To measure the extent of the individual's family network, we rely on the total number of economically active siblings. We also control for quality of the family network by constructing a measure of the frequency of visits among siblings, which may proxy for the flow of information (as well as caring, altruism, and ease of monitoring within family networks). It is important to capture other channels through which the family network might improve access to credit. For instance, family wealth may act as collateral and aid an individual in obtaining credit. Hence, we develop sibling wealth measures based on average rate of farm and nonfarm business ownership among siblings. Data on sibling wealth are not available in IFLS2, and thus we rely on information available in the first wave of the survey (IFLS1).

\section{(c) Community network variables}

Given the wide range of community-based organizations detailed in the CommunityFacility survey, it may be difficult to construct a single index of community participation. ${ }^{14}$ Our preferred measure is whether the individual has participated in the community meeting in the survey period. Grootaert (1999) provides evidence that the village governance structure is regarded as one of the most important local institutions in Indonesia. A participant in associational life is likely to gather more information about credit opportunities. This may be particularly relevant for new credit sources, including save/borrow programs, neighborhood institutions, and cooperatives. We focus on this community activity variable because it has a clear interpretation, given the robustness checks that we have identified, which include community fixed effects. An alternative measure based on the density of community-level activity at the village or townlevel will reflect associational activity, but is also likely to capture quality of infrastructure, supply of credit, and other variables, which have less to do with social networks.

We recognize that there are other channels (market interactions, kinship, ethnicity, religious groups) that can facilitate the flow of reliable information and proper enforcement for credit transactions. Therefore, we include two measures of heterogeneity at the community-level - an ethnic heterogeneity index and a Gini coefficient index. ${ }^{15}$ The ethnic heterogeneity index captures the probability that two randomly selected households speak different languages at home. Income and ethnic heterogeneity may increase the transaction costs associated with community-level production (Alesina \& LaFerrara, 2002; Okten \& Osili, 2003).

\section{(d) Contextual variables}

To control for regional variation in our data, we include province dummies in our analysis. Province dummies reflect differences in ecological environments, resource endowments, population density, and other socioeconomic differences across regions in Indonesia. We also attempt to control for the level of economic and financial development in the community using 
the distance to the nearest financial institution. The distance to the nearest financial institution is measured from the village/town center in kilometers. We also include an indicator variable, which is equal to one for urban communities (and zero otherwise).

\section{ECONOMETRIC FRAMEWORK}

In order to participate in a credit market, an individual first needs to know a place where he or she can borrow. Our analysis rests on the assumption that there are lending sources (new and established) in a particular community. The first part of our analysis models the credit application process. An individual's decision to apply depends on whether the individual has a demand for credit, as well as whether there is a perceived access to credit. For an individual to be granted a loan, the lender must deem the borrower to be creditworthy.

Our econometric framework allows us to capture the sequential nature of the credit granting process: In stage one, an individual states whether she/he knows a place where she/ he can borrow. In stage two, she/he decides whether to apply for credit. In stage three, the lender decides whether to accept or reject the loan application. We model the credit application process below.

$Y_{0}=1$ if the individual states that she/he knows a place to borrow, and zero otherwise.

$Y_{1}=1$ if the individual applies for a loan, and zero otherwise.

$Y_{2}=1$ if individual is granted a loan, and zero otherwise.

In our data, for a given individual, $Y_{1}$ is not observed unless $Y_{0}=1$. An individual is asked whether she applied for a loan only if she states that she knows at least one place from which she can borrow. Furthermore, due to the nature of the loan application process, $Y_{2}$ is not observed unless $Y_{1}=1 .{ }^{16}$ We estimate a threestage probit model and correct for the sample selection bias as in Zeller (1994).

To correct for selection bias, we include the inverse Mill's ratio from the first-stage probit model as an additional regressor in the secondstage probit. We then include the inverse Mill's ratio from the second-stage probit as an additional regressor in the third-stage probit. The omission of the inverse Mill's ratio may lead to biased estimates (Greene, 1990). This can be thought of as an omitted variable problem since the expected value of $Y_{1}\left(Y_{2}\right)$ given that $Y_{1}\left(Y_{2}\right)$ is observed depends on the probability that $Y_{0}=1\left(Y_{1}=1\right)$. By including the inverse Mill's ratio as an additional regressor, we can obtain unbiased estimates for the variables of interest.

We should note that we also do not observe all the specific lenders to which a given individual has applied for credit, but only observe the type of lender if the individual was successful in obtaining a loan. Therefore, when we analyze the determinants of obtaining credit, we do not differentiate between specific credit sources.

The second part of our analysis focuses on the factors that affect an individual's information about lending sources, with close attention to the determinants of awareness of new credit sources. In order to participate in a credit market, an individual first needs to know a place where s/he can borrow. Social networks may play an important role in improving individuals' familiarity with new credit sources.

We estimate a bivariate probit where our dependent variables are two binary choice variables, $Y_{0 \mathrm{~N}}$ and $Y_{0 \mathrm{E}}$, indicating an individual's awareness of new and established credit sources, respectively. More formally

$Y_{0 \mathrm{~N}}=1$ if individual states that she/he knows a new source to borrow from, zero otherwise.

$Y_{0 \mathrm{E}}=1$ if individual states that she/he knows an established source to borrow from, zero otherwise.

We use a bivariate probit procedure because we recognize that information about the two types of credit sources will be interdependent. We also assume that observations are correlated for individuals within the same household and independent for individuals from different households.

As discussed earlier, a problem that arises in estimating the effect of community (and family networks) is that community participation may capture unobservable individual and community traits that affect credit market access. For example, the community participation variable may be subject to endogeneity bias if individ- 
uals who wish to borrow also choose to attend the community meeting, if only to find out about other individuals' experience with the lenders. If this is the case, participation in community meetings may signal interest in borrowing, which raises the likelihood that the individual borrows. Furthermore, the lender may require the borrower to attend community meetings as a condition for loan approval.

To deal with the potential endogeneity of our community activity variable, we take the following steps. First, we instrument the participation variable using the average occurrence of community meetings (OCCUR), measured at the community level. Our instrument for individual-level participation is constructed by calculating the share of household heads who indicate that a community meeting has occurred in the community in the past 12 months. We argue that community meeting occurrence is a valid instrument because while it is correlated with individual participation in community activity (raw correlation coefficient between participation and OCCUR is 0.27 and significant at the $1 \%$ level), it is less likely to be correlated with a given individual's credit market attributes. We implement the Amemiya Generalized Least Squares (AGLS) estimator for probit with endogenous regressors. The endogenous regressors are treated as linear functions of the instruments and the other exogenous variables (Newey, 1987).

Second, we adopt a community fixed-effects specification to deal with unobserved heterogeneity at the community level. We recognize that unobserved community variables may affect both participation and credit market outcomes. For example, community participation may be influenced by quality of infrastructure, community leadership, or other less-measurable variables, which in turn affect credit market access. Thus, a positive and significant coefficient on community participation may be due to a spurious correlation between individual participation and unobserved community variables.

Finally, community participation may also reflect a high level of caring, or commitment to the community, which reduces the incentive for opportunistic behavior and may lower the probability of loan default. We introduce individual characteristics that proxy for commitment to the community, such as recent migration experience and government employee status. The addition of these variables should reduce concerns that community participation is a proxy for individual personality traits that may also affect credit access.

\section{RESULTS}

\section{(a) Credit access}

In this section, we analyze the determinants of credit access using a three-stage probit model. We investigate the role of networks on the decision to apply for credit, as well as the outcome of the credit application process. Before we decompose the credit outcome into information, application and grant processes, we estimate a reduced form regression where our dependent variable is equal to 1 if individual has received a loan and 0 otherwise (results are not shown). Our regressors include participation in community meeting, number of economically active siblings, per capita expenditure, interaction of expenditure with participation, marital status, gender, household headship, years of schooling, age, age squared, religion, household size, farm ownership, urban residence, and distance to the nearest financial institution. According to this reduced form regression, the coefficients on community (participation) and family (sibling) network variables are 0.36 and 0.03 , respectively, and significant at $1 \%$. Household heads, married, older and more educated individuals are more likely to obtain loans. Perhaps surprisingly, males and urban households are less likely to receive loans. It will be of interest to decompose these effects and examine how networks enhance credit market outcomes. Does network participation provide information to potential borrowers and encourage them to apply or does participation increase the likelihood of a positive response from the lender? Is a male individual or an urban household less likely to be aware of credit opportunities or less likely to be granted credit?

Our first-stage equation examines whether an individual is aware of any sources to obtain credit. The dependent variable at the first-stage is equal to 1 if the individual states that $\mathrm{s} / \mathrm{he}$ knows a place where s/he can borrow, and zero otherwise. The second-stage equation examines the decision to apply for credit. We correct for sample selection bias when we analyze the determinants of the loan application process (as we only observe the loan application process for individuals who state that they know a place where they can borrow). The third-stage equation allows us to study the probability that 
an individual is granted credit. We also correct for sample selection bias in the third-stage.

Table 2 presents first-stage probit estimation where we analyze the determinants of awareness of credit sources. Both community meeting participation and the number of economically active siblings have positive and significant effects on awareness of credit sources. Household heads and older individuals are more likely to state that they know a place where they can borrow. Gender, marital status, educational attainment, and wealth also appear

Table 2. Stage 1

\begin{tabular}{|c|c|}
\hline Explanatory variables & Coefficient \\
\hline \multicolumn{2}{|l|}{ Network variables } \\
\hline Participation & $\begin{array}{l}0.316^{* * *} \\
(0.033)^{\mathrm{a}}\end{array}$ \\
\hline Economically active siblings & $\begin{array}{l}0.016^{* * *} \\
(0.004)\end{array}$ \\
\hline \multicolumn{2}{|l|}{ Individual variables } \\
\hline Head & $\begin{array}{l}0.132^{* * *} \\
(0.037)\end{array}$ \\
\hline Sex $($ male $=1)$ & $\begin{array}{l}0.131^{* * *} \\
(0.033)\end{array}$ \\
\hline Marital status (married $=1$ ) & $\begin{array}{l}0.166^{* * *} \\
(0.033)\end{array}$ \\
\hline Years schooling & $\begin{array}{r}0.091^{* * *} \\
(0.004)\end{array}$ \\
\hline Muslim (=1) & $\begin{array}{c}0.049 \\
(0.052)\end{array}$ \\
\hline Age & $\begin{array}{l}0.025^{* * *} \\
(0.004)\end{array}$ \\
\hline Age squared & $\begin{array}{c}-0.350^{* * *} \\
(0.047)\end{array}$ \\
\hline \multicolumn{2}{|l|}{ Household variables } \\
\hline Per capita household expenditure & $\begin{array}{r}0.478^{* * *} \\
(0.065)\end{array}$ \\
\hline Business owner in household & $\begin{array}{l}0.124^{* * *} \\
(0.026)\end{array}$ \\
\hline Farm owner in household & $\begin{array}{c}0.006 \\
(0.030)\end{array}$ \\
\hline Household size & $\begin{array}{c}0.004 \\
(0.005)\end{array}$ \\
\hline 1 if there is a shock in 93 & $\begin{array}{c}0.052 \\
(0.064)\end{array}$ \\
\hline \multicolumn{2}{|l|}{ Community variables } \\
\hline Urban $(=1)$ & $\begin{array}{l}0.102^{* * *} \\
(0.031)\end{array}$ \\
\hline Distance to nearest financial institution & $\begin{array}{c}-0.006^{* * *} \\
(0.002)\end{array}$ \\
\hline Province dummies & Yes \\
\hline $\begin{array}{l}\text { Observations } \\
\chi^{2} \\
\text { Log likelihood } \\
R \text {-squared }\end{array}$ & $\begin{array}{c}13,872 \\
2932.8 \\
-7151.67 \\
0.17\end{array}$ \\
\hline
\end{tabular}

Dependent variable: 1 if individual knows a place to borrow.

${ }^{a}$ Standard errors in parentheses.

*** Significant at $1 \%$. 
important for being familiar with credit opportunities. We also find that household resources, measured by per capita household expenditure, and business ownership have positive and significant effects on the probability that an individual is familiar with credit sources. Urbanization is positively associated with the awareness of credit sources and statistically significant, while as might be expected distance to the nearest financial institution have a negative and significant effect on awareness.

Table 3 presents the second-stage probit estimation where we analyze the determinants of the decision to apply for credit. Our dependent variable is equal to 1 if the individual has applied for credit in the last 12 months, and zero otherwise. Social networks have an important role to play in the credit application process. We find that participation in the community meeting and the number of economically active siblings both have positive and significant effects on the decision to apply. In particular, participation in community meeting increases the probability of applying for credit by $8 \% .{ }^{17}$

Individual and household characteristics also influence the credit application decision. Similar to our earlier findings, age, household headship, and marital status are positively associated with the decision to apply to a credit source. In addition, educational attainment and household resources have a positive and significant decision on the application decision. It is interesting to note that when controlling for household headship, males are less likely to apply. Religion (Muslim=1) has a negative impact on the decision to apply for credit.

We also control for whether a household experienced a shock in the survey period. Individuals who experienced a negative shock to their income in 1997 are more likely to apply. Perhaps, surprisingly, we find that individuals from households with farm ownership are less likely to apply for credit. Community variables, such as urban residence and distance to the nearest financial institution are not significant determinants of the application decision.

Table 4 presents our third-stage probit results where the dependent variable is equal to 1 if individual is granted credit, and zero otherwise. From Table 4, we find that participation in a community meeting has a positive effect on the probability of being granted credit at $1 \%$ significance level, while number of economically active siblings is positive and significant at 10\% significance level. A change in an individual's participation status increases the probability of being granted credit by about $6 \%$. In our empirical analysis, our measures of household resources, including per capita expenditure, and farm ownership, have positive and significant effects on the probability that an individual obtains credit.

We should note that we do not find a negative and significant effect of family networks on access to credit, and hence do not find any evidence that family networks may hinder an individual's access to credit by diluting borrower's incentives as discussed in Fafchamps and Minten (2002). In fact, we find a small, positive effect of number of economically active siblings on obtaining credit. We should also note that household size has an insignificant impact on obtaining credit. Starting at the mean, an additional economically active sibling increases the probability of being granted credit by $0.04 \%$.

Our results on the effect of household debt on the probability of obtaining credit deserve close attention (Table 4, Regression 2). Household debt has a negative and significant effect on obtaining credit. These results are consistent with Zeller (1994), and indicate the lender's ability to observe the applicant's debt and asset position. From the lender's viewpoint, a high debt burden may suggest an increased risk of loan default.

We also examine closely the coefficient on the interaction term (participation $\times$ per capita expenditure level). The interaction variable (participation $\times$ per capita household expenditure) has a negative and significant effect on the probability of being granted credit. This finding may suggest that poorer individuals are more likely to benefit from social networks.

Interestingly, educational attainment, household headship, and marital status do not appear to be important determinants of obtaining credit (once we have controlled for the decision to apply). We also find that females are more likely to be granted credit. The observation that female applicants are more likely to obtain credit may provide support for Churchill's (1999) observation that lenders prefer to lend to females due to their lower default rates. It is also noteworthy that our results provide some evidence that urban households are less likely to obtain credit. This suggests that with migration from rural to urban areas, access to credit for the urban poor may be an important policy concern. It is important to note that there are significant differences in our results for the apply and grant decisions, suggesting that some lender requirements may not be satisfied by 
Table 3. Stage 2

\begin{tabular}{|c|c|}
\hline Explanatory variables & Coefficient \\
\hline \multicolumn{2}{|l|}{ Network variables } \\
\hline Participation & $\begin{array}{l}0.208^{* * *} \\
(0.039)^{\mathrm{a}}\end{array}$ \\
\hline Economically active siblings & $\begin{array}{c}0.014^{* * *} \\
(0.004)\end{array}$ \\
\hline \multicolumn{2}{|l|}{ Individual variables } \\
\hline Head & $\begin{array}{c}0.318^{* * *} \\
(0.042)\end{array}$ \\
\hline Sex $($ male $=1)$ & $\begin{array}{c}-0.124^{* * *} \\
(0.039)\end{array}$ \\
\hline Marital status (married $=1$ ) & $\begin{array}{c}0.301^{* * *} \\
(0.042)\end{array}$ \\
\hline Years schooling & $\begin{array}{c}0.014^{*} \\
(0.008)\end{array}$ \\
\hline Muslim $(=1)$ & $\begin{array}{c}-0.215^{* * *} \\
(0.053)\end{array}$ \\
\hline Age & $\begin{array}{c}0.048^{* * *} \\
(0.006)\end{array}$ \\
\hline Age squared & $\begin{array}{c}-0.587^{* * *} \\
(0.068)\end{array}$ \\
\hline \multicolumn{2}{|l|}{ Household variables } \\
\hline Per capita household expenditure & $\begin{array}{l}0.102^{*} \\
(0.055)\end{array}$ \\
\hline Business owner in household & $\begin{array}{c}0.032 \\
(0.030)\end{array}$ \\
\hline Farm owner in household & $\begin{array}{c}-0.104^{* * *} \\
(0.033)\end{array}$ \\
\hline Household size & $\begin{array}{l}0.013^{* *} \\
(0.006)\end{array}$ \\
\hline 1 if there is a shock in 97 & $\begin{array}{c}0.205^{* * *} \\
(0.035)\end{array}$ \\
\hline \multicolumn{2}{|l|}{ Community variables } \\
\hline Urban $(=1)$ & $\begin{array}{l}-0.008 \\
(0.034)\end{array}$ \\
\hline Distance to nearest financial institution & $\begin{array}{c}0.003 \\
(0.002)\end{array}$ \\
\hline Province dummies & Yes \\
\hline Mills' ratio & $\begin{array}{c}0.588^{* * *} \\
(0.186)\end{array}$ \\
\hline Observations & 9,534 \\
\hline$\chi^{2}$ & 736.81 \\
\hline Log likelihood & -6182.7838 \\
\hline$R$-squared & 0.0562 \\
\hline
\end{tabular}

Dependent variable: 1 if individual knows a place to borrow and has applied for a loan.

${ }^{a}$ Standard errors in parentheses.

* Significant at $10 \%$.

*** Significant at $5 \%$.

${ }^{* * *}$ Significant at $1 \%$.

those individuals who apply. Farm ownership probability of applying for credit, while it has was found to have a negative effect on the a positive effect on being granted credit. 
Table 4. Stage 3

\begin{tabular}{|c|c|c|c|}
\hline Explanatory variables & 1 & 2 (with debt) & 3 (IV for participation) \\
\hline \multicolumn{4}{|l|}{ Network variables } \\
\hline Participation & $\begin{array}{l}0.210^{* * *} \\
(0.064)^{\mathrm{a}}\end{array}$ & $\begin{array}{c}0.243^{* * *} \\
(0.066)\end{array}$ & $\begin{array}{l}1.560^{* * *} \\
(0.241)\end{array}$ \\
\hline Economically active siblings & $\begin{array}{l}0.012^{*} \\
(0.007)\end{array}$ & $\begin{array}{l}0.017^{* *} \\
(0.007)\end{array}$ & $\begin{array}{c}0.01 \\
(0.007)\end{array}$ \\
\hline Participation $\times$ per capita expenditure & $\begin{array}{l}-0.265^{*} \\
(0.161)\end{array}$ & $\begin{array}{l}-0.285^{*} \\
(0.164)\end{array}$ & $\begin{array}{l}-0.476 \\
(0.641)\end{array}$ \\
\hline \multicolumn{4}{|l|}{ Individual variables } \\
\hline Head & $\begin{array}{l}-0.042 \\
(0.074)\end{array}$ & $\begin{array}{l}-0.028 \\
(0.077)\end{array}$ & $\begin{array}{c}0.052 \\
(0.075)\end{array}$ \\
\hline Sex $($ male $=1)$ & $\begin{array}{c}-0.204^{* * *} \\
(0.064)\end{array}$ & $\begin{array}{c}-0.216^{* * *} \\
(0.068)\end{array}$ & $\begin{array}{c}-0.195^{* * *} \\
(0.063)\end{array}$ \\
\hline Marital status (married $=1$ ) & $\begin{array}{c}0.101 \\
(0.071)\end{array}$ & $\begin{array}{l}0.097 \\
(0.071)\end{array}$ & $\begin{array}{l}0.172^{* *} \\
(0.073)\end{array}$ \\
\hline Years schooling & $\begin{array}{l}-0.007 \\
(0.006)\end{array}$ & $\begin{array}{l}-0.01 \\
(0.006)\end{array}$ & $\begin{array}{l}-0.009 \\
(0.006)\end{array}$ \\
\hline Muslim (=1) & $\begin{array}{l}0.514^{* * *} \\
(0.061)\end{array}$ & $\begin{array}{l}0.496^{* * *} \\
(0.063)\end{array}$ & $\begin{array}{l}0.585^{* * *} \\
(0.062)\end{array}$ \\
\hline Age & $\begin{array}{c}0.01 \\
(0.011)\end{array}$ & $\begin{array}{c}0.013 \\
(0.011)\end{array}$ & $\begin{array}{l}0.024^{* *} \\
(0.011)\end{array}$ \\
\hline Age squared & $\begin{array}{l}-0.129 \\
(0.117)\end{array}$ & $\begin{array}{l}-0.168 \\
(0.122)\end{array}$ & $\begin{array}{c}-0.295^{* *} \\
(0.120)\end{array}$ \\
\hline \multicolumn{4}{|l|}{ Household variables } \\
\hline Per capita household expenditure & $\begin{array}{l}0.314^{* * *} \\
(0.114)\end{array}$ & $\begin{array}{l}0.330^{* * *} \\
(0.117)\end{array}$ & $\begin{array}{c}0.321 \\
(0.207)\end{array}$ \\
\hline Household debt in 1993 & & $\begin{array}{l}-0.01^{* * *} \\
(0.001)\end{array}$ & \\
\hline Farm owner in household & $\begin{array}{l}0.120^{* *} \\
(0.053)\end{array}$ & $\begin{array}{l}0.116^{* *} \\
(0.053)\end{array}$ & $\begin{array}{c}0.065 \\
(0.054)\end{array}$ \\
\hline Household size & $\begin{array}{c}0.009 \\
(0.009)\end{array}$ & $\begin{array}{c}0.006 \\
(0.009)\end{array}$ & $\begin{array}{c}0.013 \\
(0.009)\end{array}$ \\
\hline \multicolumn{4}{|l|}{ Community variables } \\
\hline Urban $(=1)$ & $\begin{array}{c}-0.118^{* *} \\
(0.051)\end{array}$ & $\begin{array}{c}-0.105^{* *} \\
(0.053)\end{array}$ & $\begin{array}{l}-0.129^{* *} \\
(0.052)\end{array}$ \\
\hline Distance to nearest financial institution & $\begin{array}{c}-0.011^{* * *} \\
(0.003)\end{array}$ & $\begin{array}{l}-0.012^{* * *} \\
(0.003)\end{array}$ & $\begin{array}{l}-0.007^{* *} \\
(0.003)\end{array}$ \\
\hline Mills' ratio & $\begin{array}{c}-0.927^{* * *} \\
(0.181)\end{array}$ & $\begin{array}{c}-0.846^{* * *} \\
(0.184)\end{array}$ & $\begin{array}{c}-0.562^{* * *} \\
(0.188)\end{array}$ \\
\hline Observations & 4,245 & 4,007 & 4,245 \\
\hline$\chi^{2}$ & 274.85 & 275.92 & \\
\hline Log likelihood & -2313.1137 & -2186.2341 & \\
\hline$R$-squared & 0.0561 & 0.0594 & \\
\hline
\end{tabular}

Dependent variable: 1 if granted loan.

${ }^{a}$ Standard errors in parentheses.

${ }^{*}$ Significant at $10 \%$.

${ }^{* *}$ Significant at $5 \%$.

${ }^{* * *}$ Significant at $1 \%$.

The distance to the nearest financial institution in the community has a negative and significant effect on the probability of being granted credit. This is an important result as it may imply that the costs of screening and monitoring borrowers may rise with distance 
from the financial institutions. We should note that community variables such as urban residence and distance to the nearest financial institution were not significant determinants of the application decision, while these were found to be important in being granted credit.

As we discussed in the previous section, participation may be endogenous to an individual's decision to apply for credit. In order to address this potential problem, we instrument for individual participation with average occurrence of community meeting (OCCUR) and use the predicted value from the probit estimation of participation on this variable in the analysis. The first- and second-stage probit estimations remain comparable when we instrument for individual level participation. These results are not shown, but are available upon request.

In addition, participation in community networks remains positive and significant in obtaining credit when we instrument with occurrence of community activity, which increases our confidence in our results. There are, however, some noteworthy differences for the grant equation when we instrument for participation (Table 4, Column 3). In particular, the number of economically active siblings and the interaction term of participation with per capita expenditure are no longer statistically significant in this estimation.

\section{(b) Awareness of credit sources: new versus established sources of credit}

In this section, we present results on the awareness or familiarity with new and established credit sources. The dependent variable is based on the question "Do you know a place where you can borrow?" In Table 5, we present results from the bivariate probit on access to credit from new and established institutions. In Table 6, we recognize the potential endogeneity of individual participation to awareness of credit sources and use an instrumental variable estimation method where participation is instrumented with occurrence of a community meeting (OCCUR). We also present our community fixed-effects logit results in Table 6 . We introduce additional controls for the quality of networks, and these results are presented in Table 7. Table 8 presents results for urban and rural areas, respectively.

Table 5 presents the bivariate probit results on awareness of new and established credit sources. This approach allows us to uncover differences in the effects of family and com- munity networks in circulating information about credit sources. Drawing on insights from the literature on agricultural technology adoption decisions, we predict that networks will be more important in improving awareness about new credit sources among potential borrowers.

From our results, networks appear particularly important in gaining awareness of new credit sources. Participation in a community meeting increases the probability of knowledge of new (established) credit sources by $11 \%$ $(8 \%)$. We find that family networks have positive and significant impact on familiarity with new credit sources (but it is shown to be statistically insignificant for established credit sources). Starting at the mean an additional economically active sibling increases awareness of new credit sources by $0.005 \%$. The relatively small impact of the family networks on knowledge of new credit sources can be explained by noting that the family network may be limited in its ability to provide new information due to its small group size and the tendency for incomes (and characteristics) to be highly correlated within family networks.

We interpret the above results as support for an information-based view of the role of networks in credit markets. In particular, participation in community meetings may reduce the cost of information acquisition associated with credit transactions for a potential borrower. Because potential borrows are less likely to be familiar with new credit institutions, it is not surprising that our social network measures are more important in raising awareness on new credit sources.

The household's economic position appears to play a reduced role in gaining awareness of new credit sources. In particular, household per capita expenditure has a relatively small impact on familiarity with new sources of credit, compared to its effect on established credit sources. A $10 \%$ increase in per capita household expenditure increases awareness of new (established) credit sources by $3.8 \%(7.5 \%)$. We also note that farm and business ownership are statistically insignificant in knowing a new credit source. Interestingly, men are also about $10 \%$ more likely to report familiarity with established sources of credit (while gender is statistically insignificant in familiarity with new sources of credit). There are some similarities in the effect of age, marital status, and educational attainment on the awareness of new and established sources of credit. 
Table 5. Bivariate probit estimation

\begin{tabular}{|c|c|c|c|c|}
\hline \multirow[t]{2}{*}{ Explanatory variables } & \multicolumn{2}{|c|}{ New } & \multicolumn{2}{|c|}{ Established } \\
\hline & Marginal effect & Coefficient & Marginal effect & Coefficient \\
\hline \multicolumn{5}{|l|}{ Network variables } \\
\hline Participation & 0.11 & $\begin{array}{l}0.32^{* * *} \\
(0.03)^{\mathrm{a}}\end{array}$ & 0.08 & $\begin{array}{l}0.22^{* * *} \\
(0.03)\end{array}$ \\
\hline Economically active siblings & 0.01 & $\begin{array}{c}0.02^{* * *} \\
(0.00)\end{array}$ & 0.002 & $\begin{array}{c}0.01 \\
(0.00)\end{array}$ \\
\hline \multicolumn{5}{|l|}{ Individual variables } \\
\hline Head & 0.03 & $\begin{array}{l}0.07^{* *} \\
(0.04)\end{array}$ & 0.03 & $\begin{array}{l}0.08^{* *} \\
(0.04)\end{array}$ \\
\hline Sex $($ male $=1)$ & 0.005 & $\begin{array}{c}0.01 \\
(0.03)\end{array}$ & 0.09 & $\begin{array}{c}0.24^{* * *} \\
(0.03)\end{array}$ \\
\hline Marital status (married $=1$ ) & 0.03 & $\begin{array}{l}0.08^{* *} \\
(0.04)\end{array}$ & 0.03 & $\begin{array}{l}0.08^{* *} \\
(0.03)\end{array}$ \\
\hline Years schooling & 0.03 & $\begin{array}{l}0.09^{* * *} \\
(0.00)\end{array}$ & 0.05 & $\begin{array}{l}0.11^{* * *} \\
(0.00)\end{array}$ \\
\hline Muslim (=1) & 0.04 & $\begin{array}{l}0.14^{* * *} \\
(0.05)\end{array}$ & 0.01 & $\begin{array}{c}0.03 \\
(0.05)\end{array}$ \\
\hline Age & 0.01 & $\begin{array}{l}0.02^{* * *} \\
(0.00)\end{array}$ & 0.01 & $\begin{array}{l}0.02^{* * *} \\
(0.00)\end{array}$ \\
\hline Age squared & -0.07 & $\begin{array}{l}-0.22^{* * *} \\
(0.05)\end{array}$ & -0.09 & $\begin{array}{c}-0.22^{* * *} \\
(0.05)\end{array}$ \\
\hline \multicolumn{5}{|l|}{ Household variables } \\
\hline Per capita household expenditure & 0.06 & $\begin{array}{c}0.16^{* * *} \\
(0.06)\end{array}$ & 0.20 & $\begin{array}{l}0.51^{* * *} \\
(0.08)\end{array}$ \\
\hline Business owner in household & 0.01 & $\begin{array}{c}0.03 \\
(0.03)\end{array}$ & 0.08 & $\begin{array}{l}0.20^{* * *} \\
(0.03)\end{array}$ \\
\hline Farm owner in household & -0.01 & $\begin{array}{l}-0.04 \\
(0.03)\end{array}$ & -0.01 & $\begin{array}{l}-0.02 \\
(0.03)\end{array}$ \\
\hline Household size & 0.001 & $\begin{array}{c}0.00 \\
(0.01)\end{array}$ & 0.003 & $\begin{array}{c}0.01 \\
(0.01)\end{array}$ \\
\hline 1 if there is a shock in 93 & -0.01 & $\begin{array}{c}-0.03 \\
(0.08)\end{array}$ & 0.02 & $\begin{array}{c}0.04 \\
(0.07)\end{array}$ \\
\hline \multicolumn{5}{|l|}{ Community variables } \\
\hline Urban $(=1)$ & 0.04 & $\begin{array}{c}0.12^{* * *} \\
(0.03)\end{array}$ & 0.06 & $\begin{array}{l}0.15^{* * *} \\
(0.03)\end{array}$ \\
\hline Distance to nearest financial institution & -0.003 & $\begin{array}{l}-0.01^{* * *} \\
(0.00)\end{array}$ & -0.005 & $\begin{array}{l}-0.01^{* * *} \\
(0.00)\end{array}$ \\
\hline Province dummies & & Yes & & Yes \\
\hline Observations & & 13,872 & & \\
\hline$\chi^{2}$ & & 3764.29 & & \\
\hline Log likelihood & & -14493.474 & & \\
\hline
\end{tabular}

Dependent variable: 1 if individual knows a new (established) place to borrow.

${ }^{a}$ Robust standard errors (with clustering at the household level) are in parentheses.

** Significant at $5 \%$.

*** Significant at $1 \%$.

The results on community variables appear consistent with predictions. Urban residence appears to enhance an individual's awareness of credit. We should note that urban residence was found to have a negative effect on being granted credit. Thus, while urban residents are more 
Table 6. Dependent variable: 1 if individual knows a new (established) place to borrow

\begin{tabular}{|c|c|c|c|c|}
\hline \multirow[t]{3}{*}{ Explanatory variables } & \multicolumn{2}{|c|}{$\mathrm{IV}^{\mathrm{a}}$} & \multicolumn{2}{|c|}{$\begin{array}{l}\text { Community fixed-effects } \\
\text { (logit) }\end{array}$} \\
\hline & 1 & 2 & 3 & 4 \\
\hline & New & Established & New & Established \\
\hline \multicolumn{5}{|l|}{ Network variables } \\
\hline Participation & $\begin{array}{l}1.193^{* * *} \\
(0.170)^{\mathrm{b}}\end{array}$ & $\begin{array}{c}0.109 \\
(0.161)\end{array}$ & $\begin{array}{l}0.461^{* * *} \\
(0.053)\end{array}$ & $\begin{array}{l}0.402^{* * *} \\
(0.054)\end{array}$ \\
\hline Economically active siblings & $\begin{array}{l}0.014^{* * *} \\
(0.004)\end{array}$ & $\begin{array}{c}0.006 \\
(0.004)\end{array}$ & $\begin{array}{l}0.021^{* * *} \\
(0.007)\end{array}$ & $\begin{array}{r}0.012^{*} \\
(0.007)\end{array}$ \\
\hline \multicolumn{5}{|l|}{ Individual variables } \\
\hline Head & $\begin{array}{l}-0.022 \\
(0.042)\end{array}$ & $\begin{array}{l}0.087^{* *} \\
(0.039)\end{array}$ & $\begin{array}{l}0.143^{* *} \\
(0.066)\end{array}$ & $\begin{array}{l}0.151^{* *} \\
(0.063)\end{array}$ \\
\hline Sex $($ male $=1)$ & $\begin{array}{l}-0.130^{* * *} \\
(0.044)\end{array}$ & $\begin{array}{l}0.260^{* * *} \\
(0.042)\end{array}$ & $\begin{array}{c}0.071 \\
(0.058)\end{array}$ & $\begin{array}{l}0.444^{* * *} \\
(0.056)\end{array}$ \\
\hline Marital status (married $=1$ ) & $\begin{array}{c}0.014 \\
(0.037)\end{array}$ & $\begin{array}{l}0.088^{* *} \\
(0.034)\end{array}$ & $\begin{array}{l}0.154^{* *} \\
(0.062)\end{array}$ & $\begin{array}{l}0.198^{* * *} \\
(0.058)\end{array}$ \\
\hline Years schooling & $\begin{array}{l}0.075^{* * *} \\
(0.004)\end{array}$ & $\begin{array}{l}0.116^{* * *} \\
(0.004)\end{array}$ & $\begin{array}{l}0.147^{* * *} \\
(0.007)\end{array}$ & $\begin{array}{l}0.187^{* * *} \\
(0.007)\end{array}$ \\
\hline Muslim (=1) & $\begin{array}{l}0.152^{* * *} \\
(0.051)\end{array}$ & $\begin{array}{c}0.037 \\
(0.050)\end{array}$ & $\begin{array}{l}0.260^{* *} \\
(0.116)\end{array}$ & $\begin{array}{r}-0.149 \\
(0.121)\end{array}$ \\
\hline Age & $\begin{array}{c}0.003 \\
(0.005)\end{array}$ & $\begin{array}{l}0.018^{* * *} \\
(0.005)\end{array}$ & $\begin{array}{l}0.031^{* * *} \\
(0.009)\end{array}$ & $\begin{array}{l}0.027^{* * *} \\
(0.008)\end{array}$ \\
\hline Age squared & $\begin{array}{l}-0.09 \\
(0.057)\end{array}$ & $\begin{array}{l}-0.241^{* * *} \\
(0.052)\end{array}$ & $\begin{array}{l}-0.449^{* * *} \\
(0.095)\end{array}$ & $\begin{array}{l}-0.397^{* * *} \\
(0.084)\end{array}$ \\
\hline \multicolumn{5}{|l|}{ Household variables } \\
\hline Per capita household expenditure & $\begin{array}{l}0.105^{* *} \\
(0.050)\end{array}$ & $\begin{array}{l}0.562^{* * *} \\
(0.060)\end{array}$ & $\begin{array}{c}0.207^{* *} \\
(0.087)\end{array}$ & $\begin{array}{l}0.837^{* * *} \\
(0.113)\end{array}$ \\
\hline Business owner in household & $\begin{array}{c}0.041 \\
(0.026)\end{array}$ & $\begin{array}{l}0.204^{* * *} \\
(0.025)\end{array}$ & $\begin{array}{c}0.091^{*} \\
(0.047)\end{array}$ & $\begin{array}{l}0.313^{* * *} \\
(0.046)\end{array}$ \\
\hline Farm owner in household & $\begin{array}{c}-0.075^{* *} \\
(0.031)\end{array}$ & $\begin{array}{c}-0.025 \\
(0.029)\end{array}$ & $\begin{array}{c}-0.069 \\
(0.059)\end{array}$ & $\begin{array}{c}0.103^{*} \\
(0.056)\end{array}$ \\
\hline Household size & $\begin{array}{c}0.004 \\
(0.005)\end{array}$ & $\begin{array}{c}0.010^{*} \\
(0.005)\end{array}$ & $\begin{array}{c}0.014 \\
(0.010)\end{array}$ & $\begin{array}{c}0.020^{* *} \\
(0.009)\end{array}$ \\
\hline 1 if there is a shock in 93 & $\begin{array}{r}-0.007 \\
(0.062)\end{array}$ & $\begin{array}{c}0.049 \\
(0.061)\end{array}$ & $\begin{array}{c}-0.019 \\
(0.110)\end{array}$ & $\begin{array}{c}0.119 \\
(0.110)\end{array}$ \\
\hline Community variables & & & & \\
\hline Urban $(=1)$ & $\begin{array}{l}0.133^{* * *} \\
(0.031)\end{array}$ & $\begin{array}{l}0.158^{* * *} \\
(0.030)\end{array}$ & & \\
\hline Distance to nearest financial institution & $\begin{array}{c}-0.007^{* * *} \\
(0.002)\end{array}$ & $\begin{array}{c}-0.012^{* * *} \\
(0.002)\end{array}$ & & \\
\hline Province dummies & Yes & Yes & No & No \\
\hline Observations & 13,872 & 13,872 & 13,698 & 13,862 \\
\hline
\end{tabular}

${ }^{\mathrm{a}}$ In the IV probits, participation is instrumented by the average occurrance of community meeting activity.

${ }^{\mathrm{b}}$ Standard errors in parentheses.

* Significant at $10 \%$.

** Significant at 5\%.

*** Significant at $1 \%$.

knowledgeable about credit opportunities, they seem to have more difficulty in obtaining credit. We find that the distance from the village/town center to the nearest financial institution has a negative effect on awareness of credit from both established and new credit sources. 
Table 7. Quality of networks (bivariate probit estimation) ${ }^{\mathrm{a}}$

\begin{tabular}{|c|c|c|c|c|c|c|}
\hline \multirow[t]{2}{*}{ Explanatory variables } & \multicolumn{2}{|r|}{1} & \multicolumn{2}{|c|}{2} & \multicolumn{2}{|c|}{3} \\
\hline & New & Established & New & Established & New & Established \\
\hline \multicolumn{7}{|l|}{ Network variables } \\
\hline Participation & $\begin{array}{l}0.47^{* * *} \\
(0.05)\end{array}$ & $\begin{array}{l}0.32^{* * *} \\
(0.05)\end{array}$ & $\begin{array}{l}0.31^{*} \\
(0.04)\end{array}$ & $\begin{array}{l}0.24^{* * *} \\
(0.04)\end{array}$ & $\begin{array}{l}0.30^{* * *} \\
(0.04)\end{array}$ & $\begin{array}{l}0.18^{* * *} \\
(0.04)\end{array}$ \\
\hline $\begin{array}{l}\text { Number of economically } \\
\text { active Siblings }\end{array}$ & $\begin{array}{l}0.02^{* * *} \\
(0.004)\end{array}$ & $\begin{array}{l}0.01^{* *} \\
(0.004)\end{array}$ & $\begin{array}{l}0.02^{* *} \\
(0.004)\end{array}$ & $\begin{array}{l}0.01^{* *} \\
(0.004)\end{array}$ & $\begin{array}{l}0.02^{* * *} \\
(0.01)\end{array}$ & $\begin{array}{l}0.01^{* *} \\
(0.01)\end{array}$ \\
\hline \multicolumn{7}{|l|}{ Interaction terms } \\
\hline Male $*$ participation & $\begin{array}{c}-0.25^{* * *} \\
(0.06)\end{array}$ & $\begin{array}{l}-0.17^{* * *} \\
(0.06)\end{array}$ & & & & \\
\hline $\begin{array}{l}\text { Household expendi- } \\
\text { ture } * \text { participation }\end{array}$ & & & $\begin{array}{c}0.02 \\
(0.10)\end{array}$ & $\begin{array}{l}-0.11 \\
(0.15)\end{array}$ & & \\
\hline \multicolumn{7}{|l|}{ Quality of network variables } \\
\hline $\begin{array}{l}\text { Government } \\
\text { employee }(=1)\end{array}$ & & & & & $\begin{array}{l}0.43^{* * *} \\
(0.07)\end{array}$ & $\begin{array}{l}0.28^{* * *} \\
(0.09)\end{array}$ \\
\hline Recent migrant $(=1)$ & & & & & $\begin{array}{c}0.29 \\
(0.19)\end{array}$ & $\begin{array}{l}0.15^{* * *} \\
(0.30)\end{array}$ \\
\hline $\begin{array}{l}\text { Average sibling nonfarm } \\
\text { business }\end{array}$ & & & & & $\begin{array}{c}0.05 \\
(0.06)\end{array}$ & $\begin{array}{c}0.17^{* * *} \\
(0.06)\end{array}$ \\
\hline $\begin{array}{l}\text { Frequency of visits with } \\
\text { siblings }\end{array}$ & & & & & $\begin{array}{l}-0.01 \\
(0.02)\end{array}$ & $\begin{array}{l}-0.01 \\
(0.02)\end{array}$ \\
\hline Ethnic diversity index & & & & & $\begin{array}{l}-0.12 \\
(0.08)\end{array}$ & $\begin{array}{l}-0.02 \\
(0.08)\end{array}$ \\
\hline Gini coefficient & & & & & $\begin{array}{c}0.33 \\
(0.43)\end{array}$ & $\begin{array}{c}0.83 \\
(0.42)\end{array}$ \\
\hline Number of observations & & 13,872 & & 872 & & 7,985 \\
\hline Log-likelihood & & 14482.19 & & 92.91 & & 8312.82 \\
\hline rho & & $\begin{array}{c}0.52 \\
(0.01)\end{array}$ & & $\begin{array}{l}52 \\
01)\end{array}$ & & $\begin{array}{l}0.47 \\
(0.02)\end{array}$ \\
\hline
\end{tabular}

Dependent variable: 1 if individual knows a new (established) place to borrow.

${ }^{a}$ Dependent variables are whether the individual knows an new/established source where he/she can borrow from. In our analysis, we control for age, age squared, household headship, gender, marital status, per capita household expenditure, urban residence, years of schooling, religion (muslim $=1$ ), business and farm ownership, household size, distance to financial institution and province dummies. Robust standard errors are shown in parentheses.

* Significant at $10 \%$.

** Significant at 5\%.

*** Significant at $1 \%$.

(c) Further robustness checks

\section{(i) Potential endogeneity of individual} participation

Table 6 presents univariate probit results where the dependent variable is awareness of new (established) credit sources. Here, participation is instrumented with community-meeting occurrence (OCCUR) using Amemiya Generalized Least Squares (AGLS) estimators for probit with endogenous regressors (Columns 1 and 2). ${ }^{18}$ We instrument for individual- level participation in community activity because this variable may be endogenous within the context of the borrower's or lender's decision.

It is important to note that after we instrument for our participation variable, the community network remains positive and significant for familiarity with new credit sources while it is no longer significant for knowledge of established credit sources. Again, the diffusion of information is relevant where credit sources are less familiar to potential borrowers. 
Table 8. Role of networks in rurallurban areas (bivariate probit estimation) ${ }^{\mathrm{a}}$

\begin{tabular}{|c|c|c|c|c|c|c|c|c|}
\hline \multirow{3}{*}{$\begin{array}{l}\text { Explanatory } \\
\text { variables }\end{array}$} & \multicolumn{4}{|c|}{ Rural } & \multicolumn{4}{|c|}{ Urban } \\
\hline & \multicolumn{2}{|c|}{1} & \multicolumn{2}{|c|}{2} & \multicolumn{2}{|c|}{3} & \multicolumn{2}{|c|}{4} \\
\hline & \multicolumn{2}{|c|}{ New } & \multicolumn{2}{|c|}{ Established } & \multicolumn{2}{|c|}{ New } & \multicolumn{2}{|c|}{ Established } \\
\hline $\begin{array}{l}\text { Individual } \\
\text { participation }\end{array}$ & 0.08 & $0.27^{* * *}$ & $\begin{array}{c}0.07 \\
(0.04)\end{array}$ & $0.18^{*}$ & $\begin{array}{c}0.13 \\
(0.04)\end{array}$ & $0.35^{* * *}$ & $\begin{array}{c}0.09 \\
(0.04)\end{array}$ & $\begin{array}{r}0.26^{*} \\
(0.05)\end{array}$ \\
\hline $\begin{array}{l}\text { Number of } \\
\text { economically } \\
\text { active siblings }\end{array}$ & 0.004 & $\begin{array}{l}0.012^{* *} \\
(0.006)\end{array}$ & 0.0002 & $\begin{array}{c}0.007 \\
(0.001)\end{array}$ & 0.007 & $\begin{array}{l}0.019^{* *} \\
(0.006)\end{array}$ & 0.007 & $\begin{array}{l}0.014^{* *} \\
(0.006)\end{array}$ \\
\hline $\begin{array}{l}\text { Number of } \\
\text { observations }\end{array}$ & \multicolumn{4}{|c|}{7,904} & & \multicolumn{3}{|c|}{5,968} \\
\hline
\end{tabular}

Dependent variable: 1 if individual knows a new (established) place to borrow.

${ }^{a}$ Robust standard errors (with clustering at the household level) are shown in parentheses. The dependent variables are whether an individual knows a place (new or established) where they can borrow. In our analysis, we control for age, age squared, household headship, gender (male $=1$ ), marital status, number of economically active siblings, per capita household expenditure, urban residence, yrs of schooling, religion, business and farm ownership, household size, distance to financial institution (in $\mathrm{km}$ ) and urban status. We include province dummies to control for regional variation.

${ }^{*}$ Significant at $10 \%$.

** Significant at $5 \%$.

*** Significant at $1 \%$.

Similarly, the number of economically active siblings has a positive and significant impact on awareness of new credit sources, but does not have a significant impact on established credit sources.

The results presented in Table 6 allow us to further examine differences in the determinants of awareness of credit sources. Consistent with our earlier findings, educational attainment and per capita household expenditure remain positively associated with awareness of new and established credit sources. When we instrument for participation, we find that men are less likely to report awareness of new credit sources (although they are more likely to be familiar with established credit sources).

\section{(ii) Community fixed-effects}

As discussed in Section 4, unobserved heterogeneity at the community level might affect our results on the relevance of community networks in awareness of and gaining access to credit. More specifically, unmeasured community attributes such as infrastructure, community leadership, and law enforcement may affect both access to credit and our measure of community participation, leading to a spurious relationship between credit access and networks. To address this problem of unobserved heterogeneity, we introduce a community fixedeffects logit specification. We find that participation and number of economically active siblings remain positive and significant in awareness of both new and established credit sources (Table 6, Columns 3 and 4).

Our community fixed-effects specification provides an important robustness check. Individual participation in the community meeting may reflect unobserved community attributes. For example, when we use participation in community health post (posyandu) in place of participation in community meeting, we find this variable to be positive and significant in the standard bivariate probit specification for knowing a place where one can borrow. But when we include this variable in a community fixed-effects specification, this variable is no longer statistically significant. ${ }^{19}$ The fact that our participation in community activity measure is robust to the inclusion of community fixed-effects increases our confidence in that this variable is not merely capturing unobserved community attributes, but rather the informational advantage associated with networks.

\section{(iii) Quality of networks}

An interesting question is how gender affects returns to participation. To answer this question, we include an interaction term of male with participation (Table 7, Specification 1). We find that the interaction term is negative and significant in awareness of both new and established credit sources. This implies that 
women are more likely than men to benefit from participating in community networks in gaining awareness of credit opportunities. Another policy-relevant question is how income and wealth affect the benefits from participating in community networks. One could argue that networks may confer informational advantages on the rich at the expense of the poor. To test this argument, we interact per capita expenditure with participation and include these results in Table 7, Specification 2. We find the interaction term to be insignificant in awareness of credit sources, thereby reducing concerns that the rich gain more from participating in networks.

To further control for the impact of quality of networks on access to credit, we include additional variables to measure for various aspects of networks to our baseline specification presented in Table 2 (Table 7, Specification 3).

At the individual-level, we introduce controls for recent migration and government employee status, which may proxy for commitment to the community as well as stability of future income and thus affect an individual's ability to gather information about credit opportunities. To measure the quality of the family network, we include the sibling wealth variable and the frequency of visits with siblings. To measure the quality of the community network, we include an index of ethnic diversity and the Gini coefficient.

Our results on family and community network variables remain positive and significant in awareness of credit sources. We now turn our attention to our quality of network variables. Recent migration status does not have a statistically significant impact on awareness of credit from new institutions, although it is positive and significant for established credit. ${ }^{20}$ In addition, sibling wealth has a positive and significant effect on awareness of established credit whereas it is insignificant for awareness of new credit sources. Government employee status has a positive and significant effect on awareness of both types of credit sources. We note that the frequency of visits with siblings is not a significant determinant of awareness.

The ethnic diversity index has a negative effect on awareness of credit from new sources and is significant at the $12 \%$ level of significance while it has no effect on awareness from established sources of credit. Hence, ethnic diversity does not appear to be a major impediment to the flow of information about credit market opportunities. Our additional measure of community network quality, the Gini coefficient does not have a statistically significant effect on awareness of new credit sources, while it has a positive effect on awareness of credit from established sources with significance at $10 \%$.

\section{(iv) The role of networks in urban and rural areas}

In Table 8, we present results on the relative importance of networks across rural and urban settings. Our results here suggest that community networks may have a critical role to play in urban communities. For urban households, both individual participation and number of economically active siblings have positive and significant effects on access to new and established credit sources. But social networks are shown to have a larger impact on gaining familiarity with new credit sources. Participation in a community meeting increases the probability of familiarity with new (established) credit sources by $13 \%(9 \%)$ for urban households. Starting at the mean, an additional economically active sibling increases awareness of new (established) credit sources by $0.007 \%$ $(0.005 \%)$ for urban households.

We now focus on results for rural households, with individual-level participation as the measure of the community network. Interestingly, an individual's participation in a community meeting has a smaller effect on the awareness of new (established) credit sources in rural areas. Participation in a community meeting increases the probability of awareness of new (established) credit sources by $9 \%(7 \%)$ for rural households. Again, participation in community-level activity may be less relevant for access to new credit sources in rural areas, where borrowers have access to high-quality and reliable information through other channels, such as kinship. We also note that the family network does not have a statistically significant impact on familiarity with established credit sources for rural households. As we discussed earlier, the family network may be limited in its ability to provide new information due to its small group size and the tendency for incomes (and characteristics) to be highly correlated within family networks. The correlation of family incomes and characteristics may be high in rural areas where income sources tend to be less diversified. 


\section{CONCLUSIONS}

In this paper, we investigate the role of family and community networks in enhancing access to credit. There has been very little empirical work that documents the importance of networks in credit market outcomes in developing countries.

Results from the Indonesia Family Life Surveys suggest that community participation, and to a lesser extent family networks have an important impact on an individual's ability to access credit. The empirical results also shed light on the importance of community partici- pation for women and the poor in enhancing access to credit. Community networks appear particularly important in gaining awareness of new credit sources, suggesting that networks play an important role in the diffusion of knowledge about credit opportunities.

Collective action in developing countries has been shown to affect environmental outcomes, technology adoption, and the provision of public goods. With the growing importance of microlending and other credit interventions in many low-income environments, more research is needed to uncover the role of institutions in enhancing credit market outcomes.

\section{NOTES}

1. The success of microlending programs among the poor may lie in a diverse set of mechanisms including joint liability, peer monitoring, contingent renewal, as well as social cohesion among group members (Ghatak, 1999; Ghatak \& Guinnane, 1999; Morduch, 1999; Wydick, 1999). Group lending programs may also rely on social sanctions and nonrefinancing threats to induce prompt repayment among borrowers.

2. There are a few notable exceptions: Udry (1994) discusses the role of village authorities and family elders in enforcing informal credit contracts in Northern Nigeria. Zeller (1994) shows that local formal credit institutions use locally available information about the applicant's credit-worthiness.

3. We thank an anonymous referee for pointing out this possibility.

4. The IFLS sample was selected to capture the socioeconomic diversity of the country while remaining cost-effective given size and terrain of the country-13 out of 27 provinces were sampled, and this represents $83 \%$ of the Indonesia population

5. The highly centralized nature of the Suharto regime (1968-98) meant that neighborhood associations, local associations, and town and village development councils formed part of a steeply ascending pyramid, headed by the central government. Within towns and villages, households are organized into smaller units known as Ruskin Warga (RW) and Ruku Tetangga (RT). Ruskin Warga refers to the village mutual assistance association while Ruskin Tetangga is a neighborhood association. Local residents lead the RW and RT, and these leaders are unpaid volunteers, and not employed by the government.

6. Our data also support this argument. Women, recent migrants, and individuals with lower income are less likely to participate in community meetings.

7. A quote from a survey respondent from the Indonesian report of Voices of the Poor illustrates this point: http://www.worldbank.org/poverty/voices/reports/ national/indon5-7.pdf (p. 87): Krungu Krungu untuk bantuan (which is translated as follows: "I heard rumors of assistance, but no one seems to know where it is").

8. The precursor to the modern BRI was the Hulp-en Spaarbank der Inlandsche Bestuurs Ambtenaren, or 'The Assistance and Savings Bank for Native Government Employees' which was founded in 1895 in Central Java.

9. At the BRI units, collateral is used as a symbol of the client's commitment, not a secondary repayment source (Churchill, 1999) as units almost never seize the collateral of clients in the case of delinquent repayment.

10. This idea builds on a well-known literature on the role of nonmarket institutions in dealing with credit market imperfections. See Stiglitz and Weiss (1981) and Varian (1990). Social collateral and reputation play a crucial role in determining access to credit (Besley \& Coate, 1995).

11. In many parts of Indonesia, the role of women in community activity tends to be limited, and their influence in community issues tends to occur through women's groups and associations (Mukherjee, 2002, p. 15). 
12. See Frankenberg and Thomas (2000) for a detailed description of the IFLS surveys.

13. We exclude family lending from our empirical analysis, but note that there is a high degree of reliance on family members for access to credit. About $35 \%$ of our sample of individuals report that they can borrow from family. There is considerable overlap in categories, which suggests that a large share of our sample participate in both family and nonfamily credit networks. About 10\% report that they can borrow from family only, $30 \%$ report formal credit access only, $2 \%$ report informal credit access only, and $12 \%$ report that they can borrow from both formal and informal lenders.

14. Okten and Osili (2003) study the factors that contribute to existence of community organizations in Indonesia.

15. Our Gini coefficient index was constructed using per capita household expenditure data, and it is computed at the kecamatan (district) level. The Gini coefficient index is used as a measure of inequality in a community.

16. Previous studies have observed that certain individuals may not apply for a loan if they do not expect to receive a loan offer. These individuals may be considered discouraged borrowers, and may be quite similar to loan applicants who were denied credit (Zeller, 1994). Our sample of credit applicants may not contain a large number of discouraged borrowers as we expect that discouraged borrowers are less likely to report that they know a place to borrow.

17. Marginal effects of all variables though not presented are available upon request.

18. We also tried a different IV method suggested by a referee. We estimated a first-stage ordinary least squares (OLS) regression of the participation on all exogenous variables and instruments. We then obtained the residuals from this regression and added the residuals in the second step limited dependent variable regression, in addition to the un-instrumented participation variable. Participation variable remains positive and significant comparable to results presented in the paper using AGLS. The residuals are insignificant for the established credit sources while they are negative and significant for the new credit sources. This suggests that our concerns for the possible endogeneity of the participation variable are especially valid for awareness of new credit sources.

19. These results, though not shown, are available upon request.

20. At first glance, this result may appear puzzling since recent movers may lack information that are important in having access to credit. We explain this result by noting that movers in our data are more likely to live in urban areas than nonmovers. It is possible, however, that the decision to move may be endogenous to having access to credit.

\section{REFERENCES}

Adams, D. W., \& Fitchett, D. A. (1992). Informal finance in low-income countries. Boulder, CO: Westview Press.

Aleem, I. (1990). Imperfect information, screening, and the costs of informal lending: a study of a rural credit market in Pakistan. World Bank Economic Review, 4(3), 329-349.

Alesina, A., \& LaFerrara, E. (2002). Who trusts others? Journal of Public Economics, 85(2), 207234.

Besley, T. (1995). Nonmarket institutions for credit and risk sharing in low-income countries. Journal of Economic Perspectives, 9(3), 115-127.

Besley, T., \& Coate, S. (1995). Group lending, repayment incentives and social collateral. Journal of Development Economics, 46(1), 1-18.

Churchill, C. (1999). Client-focused lending: the art of individual lending. Toronto: Calmeadow.

Conley, T.G. \& Udry, C.R. (2003). Learning about a new technology: pineapple in Ghana. Mimeo. Department of Economics, Yale University, New Haven, CT.
Fafchamps, M., \& Minten, B. (2002). Returns to social network capital among traders. Oxford Economic Papers, 54(2), 173-206.

Feder, G., Just, R. E., \& Zilberman, D. (1985). Adoption of agricultural innovations in developing countries: a survey. Economic Development and Cultural Change, 33(2), 255-298.

Foster, A. D., \& Rosenzweig, M. R. (1995). Learning by doing and learning from others: human capital and technical change in agriculture. Journal of Political Economy, 103(6), 1176-1209.

Frankenberg, E., \& Karoly, L. (1995). The 1993 Indonesian Family Life Survey: overview and field report. RAND Santa Monica, CA.

Frankenberg, E. \& Thomas, D. (2000). The Indonesia Family Life Survey (IFLS): study design and results from waves 1 and 2. DRU-2238/1-NIA/NICHD. RAND, Santa Monica, CA.

Fukuyama, F. (1995). Trust. New York: Free Press.

Ghatak, M. (1999). Group lending, local information and peer selection. Journal of Development Economics, 60(1), 27-50. 
Ghatak, M., \& Guinnane, T. W. (1999). The economics of lending with joint liability: theory and practice. Journal of Development Economics, 60(1), 195-228.

Granovetter, M. (1974). Getting a job: A study of contacts and careers. Cambridge, MA: Harvard University Press.

Greene, W. (1990). Econometric analysis. New York: Macmillan Publishing Company.

Grootaert, C. (1999). Local institutions and service delivery in Indonesia World Bank. Local level institutions working paper no 5, World Bank, Washington, DC.

Isham, J. (2002). The effect of social capital on fertilizer adoption: evidence from rural Tanzania. Journal of African Economies, 11(1), 39-60.

Jacoby, H. G., \& Skoufias, E. (1997). Risk, financial markets, and human capital in a developing country. The Review of Economic Studies, 64(3), 311-335.

Kranton, R. E. (1996). Reciprocal exchange: a selfsustaining system. American Economic Review, 86(4), $830-851$.

Montgomery, J. D. (1991). Social networks and labormarket outcomes: toward an economic analysis. American Economic Review, 81(5), 1407-1418.

Morduch, J. (1999). The microfinance promise. Journal of Economic Literature, 37(4), 1569-1614.

Mukherjee, N. (2002). Indonesia: coping with vulnerability and crisis. In D. Narayan \& P. Petesch (Eds.), Voices of the poor: From many lands. New York: Oxford University Press.

Munshi, K. (2003). Networks in the modern economy: mexican migrants in the us labor market. Quarterly Journal of Economics, 118(2), 549-599.

Narayan, D., \& Pritchett, L. (1999). Cents and sociability: household income and social capital in rural Tanzania. Economic Development and Cultural Change, 47(4), 871-897.

Newey, W. K. (1987). Efficient estimation of limited dependent variable models with endogenous explanatory variables. Journal of Econometrics, 36(3), 231250 .
Okten, C., \& Osili, U. O. (2003). Contributions in heterogeneous communities: evidence from Indonesia. Journal of Population Economics.

Pitt, M. M., \& Khandker, S. R. (1998). The impact of group-based credit programs on poor households in Bangladesh: does the gender of participants matter? Journal of Political Economy, 106(5), 958-996.

Portes, A. (1998). Social capital: its origins and applications in modern sociology. Annual Review of Sociology, 24(1), 1-26.

Putnam, R. et al. (1993). Making democracy work: Civic traditions in modern Italy. Princeton, NJ: Princeton University Press.

Robinson, M.S. (1994). Financial intermediation at the local level: lessons from indonesia. Part two: a theoretical perspective. Development Discussion Papers \#482. Harvard Institute for International Development, Cambridge, MA.

Seibel, H.D. \& Parhusip, U. (2003). Microfinance in Indonesia: an assessment of microfinance institutions banking with the poor. Economics and Sociology Occasional Paper No. 2365, Department of Agricultural Economics, Ohio State University, Columbia, $\mathrm{OH}$.

Stiglitz, J. E., \& Weiss, A. (1981). Credit rationing in markets with imperfect information. American Economic Review, 71(3), 393-410.

Udry, C. (1994). Risk and insurance in a rural credit market: an empirical investigation in Northern Nigeria. Review of Economic Studies, 61(3), 495-526.

Varian, H. (1990). Monitoring agents with other agents. Journal of Institute of Theoretical Economics, 146, 153-174.

Wydick, B. (1999). Can social cohesion be harnessed to repair market failures? Evidence from Group Lending in Guatemala. Economic Journal, 109(457), 463475.

Zeller, M. (1994). Determinants of credit rationing: a study of informal lenders and formal credit groups in Madagascar. World Development, 22(12), 18951907. 